\title{
Regna duo duorum. Berthold of Moosburg's Theory of Providence and Fate
}

\author{
Alessandro Palazzo \\ Università di Trento
}

Berthold's reflections on providence were part of a lively debate which took place in Germany between the mid-13th century and the third quarter of the 14th century, involving the chief German theologians of the Dominican Order: Albert the Great, Ulrich of Strassburg, Dietrich of Freiberg, and Meister Eckhart.

The centrality of natural providence in the philosophy of Berthold of Moosburg is unquestionable. In a well-known and oft-cited locus of the Expositio tituli, Berthold states that the subject of the Elementatio theologica is the universe (universitas) of divine things considered in their procession from, and their return to, the Highest Good within the order of natural providence. The ratio subiecti of this theological science is the Divine Good, which belongs in a simple, causal, and primary way to the First Principle of all things, whereas it resides relatively (in attributione ad ipsum) in divine things per essentiam and per participationem. Therefore, it can be affirmed that the subject of the Elementatio theologica is the Divine Good according to natural providence. ${ }^{1}$

1 Berthold of Moosburg, Expositio super Elementationem theologicam. Prologus. Propositiones 1-13, eds. M.R. Pagnoni-Sturlese, L. Sturlese (Hamburg: Meiner, 1984), Expositio tituli I, p. 46, 1. 319-p. 47, 1. 342: Et quia totus iste liber tractat de rerum divinarum universitate secundum processum eius a summo bono et regressum in ipsum, et hoc secundum dispositionem et proprios modos earum inditos ipsis rebus divinis ab eo, quod est divinum principaliformiter sive secundum causam, et hoc secundum ordinem providentiae naturalis, non iam proprie voluntariae, iuxta distinctionem Augustini VIII Super Genesim ad litteram, necesse est omnia convenire, de quibus hic tractatur, in una ratione subiecti, propter quam etiam ista philosophia est una scientia. Quod subiectum vocetur, sicut et vere est, bonum divinum, quod simpliciter et absolute causaliter seu principaliformiter convenit omnium primo principio, reliquis autem bonis, puta divinis per essentiam et per participationem, in attributione ad ipsum, et hoc quantum ad modos attributionis, quos distinguit Averroes super principium IV Metaphysicae, scilicet ut ad efficiens primum et finem ultimum nec non ut accidentia ad subiectum. [...] Ex praedictis apparet, quod bonum divinum secundum ordinem providentiae naturalis est subiectum huius libri, quod exprimitur per li: ELEMENTATIO THEOLOGICA. See also Berthold of Moosburg, Expositio, Exp. tit. I, p. 45, 1. 280-281: Materialis quidem subiectiva, quia in ipso tractatur per elementorum coordinationem de bono divino secundum ordinem providentiae naturalis. The

(C) ALESSANDRO PALAZZO, $2021 \mid$ DOI:10.1163/9789004471023_013

This is an open access chapter distributed under the terms of the CC BY-NC 4.Alicessanse ro palazzo - 9789004471023 
Elsewhere, Berthold maintains more straightforwardly that the act of natural providence is the subject of this book. ${ }^{2}$ By contrast, voluntary providence is said to be the subject of dogmatic theology ${ }^{3}$ and is usually exemplified by the Dionysian hierarchy, the angels, and their hierarchical mutual operations. ${ }^{4}$

Unsurprisingly, therefore, when it comes to providence, modern scholars have mainly devoted their attention to the concept of twofold providence (gemina providentia), first theorized by Augustine in Book vill of De Genesiad litteram, ${ }^{5}$ and originally reformulated by Ulrich of Strassburg (De summo bono

source of the longer quotation is a locus of Dietrich's De subiecto theologiae, the only difference being the fact that, unlike Berthold, Dietrich is concerned with defining the subject of theology, not philosophy: see De subiecto theologiae, ed. L. Sturlese, in Opera omnia, vol. 3. Schriften zur Naturphilosophie und Metaphysik, eds J.-D. Cavigioli et al. (Hamburg: Meiner, 1983), 3.9, p. 281, l. 100-p. 282, l. 109. On the locus of the De subiecto theologiae and Dietrich's notion of twofold providence, see L. Sturlese, "Introduzione" to Berthold of Moosburg, Expositio super Elementationem theologicam Procli. 184-211. De animabus, ed. L. Sturlese (Roma: Edizioni di Storia e Letteratura, 1974), p. xv-xcii, at p. xxvi-xxxiv; L. Sturlese, "Il De animatione caeli di Teodorico di Freiberg", in R. Creytens, P. Künzle (eds), Xenia Medii Aevi historiam illustrantia oblata Thomae Kaeppeli O. P., 2 vols (Roma: Edizioni di Storia e Letteratura, 1978), vol. 1, p. 175-247, at p. 183-201; A. de Libera, Introduzione alla mistica renana (Milano: Jaca Book, 1998), ch. 7, p. 244-246; L. Sturlese, Storia delle filosofia tedesca nel Medioevo. Il secolo XIII (Firenze: Olschki, 1996), p. 204-213.

2 See below, n. 31.

3 Berthold, Expositio, Praeambulum, p. 53, l. 19-20: theologia, quae est de bono divino secundum ordinem providentiae voluntariae, fundatur in principiis creditis, quae sunt articuli fidei Christianae.

4 Interestingly, Berthold inverts the usual scheme when he first refers to twofold providence, for he quotes a passage from Dionysius' De divinis nominibus to illustrate the invisibilia Dei transitive accepta according to natural providence - these are the primordial causes and their effects, which are both the subject of the Elementatio theologiae - whereas he cites a text from Proclus' De malorum subsistentia to clarify the invisibilia Dei belonging to voluntary providence: see Expositio, Prologus 5-6, p. 13, l. 251-278. The latter text is also used to illustrate voluntary providence elsewhere: see Berthold of Moosburg, Expositio super Elementationem theologicam. Propositiones 136-159, ed. F. Retucci (Hamburg: Meiner, 2007), 161C, p. 12, 1. $46-53$.

5 Augustine, De Genesi ad litteram libri duodecim, ed. J. Zycha (Praha / Wien / Leipzig: Tempsky, 1894), VIII.9, p. 243, l. 25-p. 244, l. 18: hinc iam in ipsum mundum uelut in quandam magnam arborem rerum oculus cogitationis adtollitur atque in ipso quoque gemina operatio prouidentiae reperitur, partim naturalis, partim uoluntaria. Et naturalis quidem per occultam dei administrationem, qua etiam lignis et herbis dat incrementum, uoluntaria uero per angelorum opera et hominum; secundum illam primam caelestia superius ordinari inferius que terrestria, luminaria sidera que fulgere, diei noctis que uices agitari, aquis terram fundatam interlui atque circumlui, aerem altius superfundi, arbusta et animalia concipi et nasci, crescere, senescere, occidere et quidquid aliud in rebus interiore naturali que motu geritur; in hac autem altera signa dari, doceri et disci, agros coli, societates administrari, artes exerceri et quaeque alia siue in superna societate aguntur siue in hac terrena atque mortali, ita ut bonis consulatur et per 
II.5.18) and Dietrich of Freiberg (in several works). It has therefore been argued that Berthold aligned himself with his Dominican predecessors who made recourse to twofold providence as an epistemological tool aimed at separating the fields of philosophy and theology. ${ }^{6}$ This line of interpretation is defective, however, because it ends up neglecting other important aspects of Berthold's theory of providence.

Furthermore, by exclusively focusing its attention on twofold providence, modern scholarship is inclined to read Berthold's conceptions through the filter of the views of his predecessors, who attached fundamental importance to Augustine's distinction between natural and voluntary providence. Even though it cannot be denied that Berthold was indebted to both Ulrich and Dietrich, ${ }^{7}$ it must nevertheless be pointed out that his analysis advances

nescientes malos; in que ipso homine eandem geminam prouidentiae uigere potentiam: primo erga corpus naturalem, scilicet eo motu, quo fit, quo crescit, quo senescit; uoluntariam uero, quo illa ad uictum, tegumentum curationem que consulitur.

6 Sturlese, "Il De animatione caeli", p. 193-196; K. Flasch, "Einleitung", in Berthold of Moosburg, Expositio super Elementationem theologica. Prologus. Propositiones 1-13, p. xi-xxxvii, at p. xxxi-xxxii; G.L. Potestà, "Per laboriosam investigationem ascendendo. L'edizione di Bertoldo di Moosburg", in Rivista di Filosofia Neo-Scolastica 76(1984), p. 637-643, at p. 642; R. Imbach, "Au-delà de la métaphysique. Notule sur l'importance du Commentaire de Berthold de Moosburg op sur les Éléments de théologie", in D. Calma (ed.), Reading Proclus and the Book of Causes. Volume 1. Western Scholarly Networks and Debates (Leiden / Boston: Brill, 2019), p. 376-393, at p. 380-381; A. Beccarisi, "Einleitung", in Ulrich of Strassburg, De summo bono. Liber 2, Tractatus 5-6, ed. A. Beccarisi (Hamburg: Meiner, 2007), p. vii-xx, at p. xix-xx. By contrast, W. Eckert, "Berthold von Moosburg O.P. Ein Vertreter der Einheitsmetaphysik im Spätmittelalter", in Philosophisches Jahrbuch 65(1957), p. 120-133, at p. 133, argues that the distinction between the two providences is aimed at using theological principles to explain Proclean thought, since philosophy and theology - which are identified by the two providential orders - deal with the same subject, the Highest One considered from two different points of view. According to de Libera, Introduzione alla mistica renana, p. 246-247, n. 24, even though twofold providence serves to provide the distinction between philosophy and theology with a systematic foundation, Proclus is both a philosopher and a theologian and brings together the methods of both disciplines.

7 I draw attention to a hitherto overlooked passage from Albert's Summa theologiae: Albert the Great, Summa theologiae. Pars prima, ed. A. Borgnet, Opera omnia, vol. 31 (Paris: Vivès, 1894), Ia, tr. 17, q. 68, m. 3, p. 703b-704a: Sunt alia per duos ordines causarum a providentia descendentia, scilicet per ordinem causarum naturalium [...]. Est iterum ordo causarum in his quae descendunt a providentia per liberum arbitrium. See also Albert the Great, Summa theologiae, Ia, tr. 17, q. 68, m. 1, p. 695a. Even though a textual dependence seems improbable, it cannot be excluded that the text was known by and influenced Berthold. As is well known, the Summa theologiae was one of the most prominent sources in Berthold's Exposition on the Elements of Theology. See L. Sturlese, "Rec. a Alberti Magni Summa theologiae sive de mirabili scientia Dei, Libri I pars 1, Quaestiones 1-50A, ed. D. Siedler, Münster i.W., Aschendorff, 1978", in Annali della Scuola Normale Superiore di Pisa 10(1980), p. 1691-1698, at p. 1693-1697. The complex ways in which the Summa theologiae was used by Berthold have been carefully 
original concepts, deals with hitherto unexplored issues, and put forward innovative solutions. In a word, Berthold faced the intellectual challenge posed by Proclus' Opuscula, from which he derived key elements, such as the threefold One or Good (secundum causam, per essentiam, secundum participationem), the theory of the two regna (providence and fate), providential knowledge (cognitio providentionalis), etc. The Elements of Theology also offers a complex and articulate theory of providence, giving Berthold the opportunity to discuss crucial questions, such as how providence differently resides in the One-Good and in the rest of reality and how it transcends the things for which it provides. Even though he was familiar with Proclus' masterpiece, Dietrich of Freiberg did not deal with these topics.

In what follows, I intend to explore some of the issues which Berthold discusses with regard to providence. In particular, I will devote my attention to the dialectical relationship between the domains of providence and fate. As we will see, the delineation of the two realms is made possible by the adoption of two different approaches to providence, one top-down and the other bottom-up. It is within this specific doctrinal context that I will also refer to the concept of twofold providence.

My analysis will focus on Berthold's commentary on a few particularly relevant Propositions $(141,120,122$, and 34$)$ in an attempt to reconstruct the main steps in Berthold's reflections on providence. Attention will be given to several sources (Proclus' Opuscula, Boethius' De consolatione philosophiae, Ulrich's De summo bono, Cicero's De natura deorum) that Berthold quotes from, in addition to the Elements of Theology.

The starting point of my analysis is the Tabula contentorum at the end of the Expositio, a document usually neglected by Berthold scholars. The Tabula is a list of the main topics discussed by Berthold and includes references to the

studied by M.R. Pagnoni-Sturlese, "À propos du néoplatonisme d'Albert le Grand. Aventures et mésaventures de quelques textes d'Albert dans le Commentaire sur Proclus de Berthold de Moosburg", in Archives de Philosophie 43(1980), p. 635-654; E. King, "Eriugenism in Berthold of Moosburg's Expositio super Elementationem theologicam Procli”, in D. Calma (ed.), Reading Proclus. Vol. 1, p. 395-437, at p. 401-410. 
numbers of the propositions where these topics are discussed. Whether compiled by Berthold himself or by someone else, at his request, this is a valuable hermeneutical tool, as it provides specific access to the text ad mentem auctoris. ${ }^{8}$

\section{PROVIDENTIA, PROVIDERE}

Quod quidam negaverunt providentiam esse 120 (D). Ostenditur multipliciter providentiam esse. Quod omnis deus in sua existentia habet totum providere (F). Quod providentia primitus est in diis (I). Quid sit providentia (D). Quod providentia est duplex, scilicet naturalis et voluntaria (L). Quid sit ratio providendi (G). Quomodo providere conveniat pluribus $(\mathrm{H})$.

De duplici providentia 121 (L).

Quod est prime providens 122 (A). Quod omne divinum est primum providens in sua universitate. Quod est inpausabiliter providens et universaliter. Que sit condicio provisorum.

Quod omne divinum providet essentialiter, universaliter et inpausabiliter seu incessabiliter. Provisorum diversificatio (D). Actus providendi difformis participatio (E). Actus providendi ad omnia eternalis extensio (F). Actus providendi primitus providentium condicio $(\mathrm{G})$. Quod pervenit ad omnia intentioni providentis subiecta $(\mathrm{H})$. Quod prime providens est exemptum a providentibus (I). Quid sit inmiscibilitas et inhabitudinalitas divinorum $(\mathrm{K})$. Quod providentia et unialis excellentia conpatiuntur se (L). Quod excellentia non submittitur nec providentia exterminatur (M). Cognitionis intellectualis et providentionalis differentia 134 (D). Item distinctio intelligendi et providendi (E). Quod omnis intellectus divinus providet ut deus (F).

Distinctio providentie in naturalem et voluntariam secundum Augustinum 141 (A). Providentie et fati distinctio (B). Omnis providentie causa et ratio et eius bipartita divisio (D). Providentie exempte modus et condicio (E). Providentie coordinate propria intentio (F). Quod in ordine providentie naturalis est duplex processus $146 \mathrm{~B} .{ }^{9}$

The section entitled Providentia, providere is one of the longest in the Tabula, taking up almost a page and a half. The reader is struck by the number of

8 L. Sturlese, "Presentazione", in Berthold of Moosburg, Tabula contentorum in Expositione super Elementationem theologicam Procli, ed. A. Beccarisi (Pisa: Scuola Normale Superiore, 200o), p. vii-xi, at p. x: "accesso puntuale al testo, per così dire, ad mentem auctoris".

9 Berthold of Moosburg, Tabula contentorum, p. 132-133. 
topics related to providence: the existence of providence ("Quod quidam negaverunt providentiam esse") and its definition ("Quid sit providentia"); how providence resides in the divine (e.g. "Omnis deus in sua existentia habet totum providere", "Quod providentia primitus est in diis", "Quod omne divinum est primum providens in sua universitate", etc.); how inferior beings are subject to providence ("Que sit condicio provisorum"); the difference between knowledge according to providence and intellectual knowledge ("Cognitionis intellectualis et providentionalis differentia"; "Item distinctio intelligendi et providendi"); the transcendence and universality of providence ("Actus providendi ad omnia eternalis extensio"; "Quod pervenit ad omnia intentioni providentis subiecta"; "Quod prime providens est exemptum a providentibus"; etc.), and so on. Considered within this large cluster of theologico-metaphysical themes, the concept of a twofold providence, which is referred to three times, it is only one important issue among several others. ${ }^{10}$

Moreover, the distinction Berthold draws between providence and fate ("Providentie et fati distinctio", 141B) reveals a link to topics related to both the realm of celestial causality - evoked by such headings as "Peryodus, Peryodicum, Annus: De magno anno" (198 [F]) and Astra ${ }^{11}$ - and the world of nature - referred to as Natura..$^{12}$ In other words, the providence-fate distinction allows us to identify a bottom-up perspective on providence and also conduct the analysis at the level of the philosophy of nature.

\section{The Realm of Providence and the Realm of Fate}

Proposition 141 ("Omnis providentia deorum haec quidem est exempta ab his, quibus providetur, haec autem coordinata") is one of the most cited under the heading Providentia, providere in the Tabula contentorum. In the commentary on this proposition, Berthold addresses some of the most salient motifs in his theory of providence.

10 See Berthold of Moosburg, Tabula contentorum, p. 133, 1. 584-585: Quod providentia est duplex, scilicet naturalis et voluntaria $(L)$ [the correct reference would be to $12 \mathrm{OE}$ ]; 1.587 : De duplici providentia $121(L)$ [however, the reference is not to twofold providence, but to cognitio providentiae]; 1. 603: Distinctio providentiae in naturalem et voluntariam secundum Augustinum 141 (A).

11 See Berthold of Moosburg, Tabula contentorum, p. 119, l. 246-256; p. 17, l. 378-379; p. 22, 1. $502-504$.

12 See Berthold of Moosburg, Tabula contentorum, p. 98, 1. 26-p. 99, 1. 58. One should note that Berthold lists Naturalis providentia as the first item after Natura: p. 99, 1. 59-61. 
In the suppositum, he deals with the issue of twofold providence. It must be noted that in this case, in contrast with comments he makes elsewhere, Berthold does not evoke this concept for methodological reasons, that is, with a view to distinguishing divinissima philosophia, subject of the Elementatio theologiae, from Christian philosophy.

De primo sciendum, sicut aliqualiter dictum est super 120, duplex est providentia, naturalis scilicet et voluntaria. Et habetur ista distinctio ab Augustino vin Super Genesim ad litteram, ubi dicit tractans illud verbum "ut operaretur et custodiret": "Hinc iam in ipsum mundum velut in quandam magnam arborem rerum oculus cogitationis attollitur atque in ipso quoque gemina operatio providentiae reperitur, partim naturalis, partim voluntaria. Naturalis quidem per occultam Dei administrationem, quae et lignis et herbis dat incrementum, voluntaria vero per angelorum opera et hominum. Secundum illam primam caelestia superius ordinari inferii usque terrestria, lumina sideraque fulgere" - et infra - "et quidquid aliud in rebus interiore naturalique motu geritur. In hac autem altera signa dari, doceri et discere, agros coli, societates administrari, artes exerceri, et quaeque alia sive in superna societate aguntur sive in hac terrena atque mortali ita, ut bonis consolatur". Et infra: "Deus itaque super omnia, qui condidit omnia et regit omnia, omnes naturas bonus creat, omnes voluntates iustus ordinat". Haec Augustinus. ${ }^{13}$

Among the mentions of twofold providence scattered throughout Berthold's Expositio, this passage has two peculiarities. First, Berthold directly and explicitly quotes from the Book viII of the De Genesi ad litteram - a rare occurrence in the Expositio. Secondly, this is the only time Augustine's text is cited extensively. As the consequence, natural providence is exemplified as the growing of trees and herbs, the order of celestial and terrestrial phenomena, the shining of lights and lightning, and whatever else takes place in things due to their intrinsic and natural movements. From all these examples, the physical character of natural providence clearly emerges. Whereas in the Expositio tituli, for instance, the order of natural providence coincides with the all-encompassing metaphysical movement of the procession from, and return to, the One, here natural providence is interpreted as the orderly structure of physical phenomena and in fact is the same as the realm of fate described in the passage from

13 Berthold of Moosburg, Expositio, 141A, p. 45, l. 11-24. As for the quotation of Augustine, see above, n. 5 . 
Proclus' On Providence and Fate (De providentia et fato) cited only a few pages later. This physical understanding of natural providence is made easier by a seemingly minimal, but in fact highly significant, divergence from De Genesiad litteram; whereas Augustine refers to the twofold operation of a single providence (gemina operatio providentiae), Berthold mentions a twofold providence (duplex est providentia), thus paving the way for the identification of natural providence with what he would later define as "the realm of fate".

In all likelihood, Ulrich of Strassburg's De summo bono is the origin for the interpretation of natural providence as fate.

Dicit enim Augustinus viII libro Super Genesim: "Gemina operatio providentiae reperitur: partim naturalis, per quam dat lignis et herbis incrementum, partim voluntaria per operationem angelorum et hominum". Secundum primum actum providentiae est ordo naturalis causarum, quem philosophi determinant, scilicet quod primo sunt causae universales, scilicet caelestia et motus eorum, et sub illis sunt causae particulares. Cum ergo omnis artifex operans per instrumentum dispositionem artis instrumentis infundat, necessario dispositio divinae providentiae huic conexioni causarum infunditur. Haec ergo dispositio providentiae infusa toti isti conexioni causarum fatum vocatur, ut dicit Boethius, prout philosophi de fato loquuuntur. ${ }^{14}$

In this text, Ulrich transforms what was originally an operation of providence into a natural order of causes which descend from the universal (i.e., the celestial bodies and their motions) to the particular. Even though this does not reach the explicit idea of a realm of fate, it comes a step closer by suggesting the existence of a structure that underpins the natural universe.

Ulrich's mention of Boethius' conception of fate is telling. Unsurprisingly, Berthold takes this clue and develops it further. In the suppositum, when it comes to clarifying the relationship between providence and fate, he quotes the classical locus from On the Consolation of Philosophy, Book IV, prose 6 dealing

14 Ulrich of Strassburg, De summo bono, lib. II, tr. 5, c. 18, §9, p. 145, l. 263-p. 146, l. 272. The fact that Berthold quotes a larger part of the Augustinian source than Ulrich does confirms that he had direct access to Augustine's De Genesi ad litteram. On Ulrich's conception of fate, see A. Beccarisi, "La scientia divina dei filosofi nel De summo bono di Ulrico di Strasburgo", in Rivista di Storia della filosofia 61(2006), p. 137-163, at p. 147-152; A. Palazzo, "Ulrich of Strasbourg's Philosophical Theology. Textual and Doctrinal Remarks on De summo bono" in A. Speer, Th. Jeschke (eds), Schüler und Meister (Berlin / Boston: De Gruyter, 2016), p. 205-242, at p. 219-241. Twofold providence is discussed at pages p. 222-228. 
with providence and fate. ${ }^{15}$ There, Boethius considers fate to be the chain of causes by which the simple and eternal decree of divine providence unfolds in space and time. This is the core concept from which Boethius draws several important consequences, such as the conclusion that everything subject to fate is also subordinate to providence, but not vice versa; that fate is a disposition inhering in mutable things; that the beings close to the First Divinity are beyond the mutable order of fate, etc. This text allows Berthold to conceptualize the crucial issue of the temporalization of the disposition of the divine mind. As already seen in Ulrich, providence and fate are clearly distinguished: one coincides with the intuition of all reality in the divine mind, the other with the temporal series or connection of causes. Yet, they are interrelated: the latter is the unfolding of the former. Nowhere, however, does Boethius refer to two realms.

It is on the basis of a long passage quoted from Proclus' On Providence and Fate that Berthold explicitly theorizes the existence of two hierarchically ordained realms: that of providence and that of fate. On Providence and Fate is one of Proclus' Tria opuscula which deal with providence, fate, freedom and evil. Translated from Greek into Latin by William of Moerbeke in 1280, they did not enjoy wide circulation. ${ }^{16}$ Berthold, however, made extensive recourse to these treatises with specific regard to the theory of unum animae. ${ }^{17}$ They are also crucial sources for Berthold's theory of providence, as is clear from this and other passages throughout his Expositio, some of which we will discuss below. 18

15 Berthold of Moosburg, Expositio, 141B, p. 46, l. 42-p. 47, l. 66. See Boethius, De consolatione philosophiae, ed. C. Moreschini (München / Leipzig: Saur, 200o), lib. IV, prosa 6, §7-17, p. 122, l. 20-p. 124, l. 77 .

16 C. Steel, "William of Moerbeke, Translator of Proclus", in S. Gersh (ed.), Interpreting Proclus. From Antiquity to the Renaissance (Cambridge: Cambridge University Press, 2014), p. 247-263, at p. 251-253.

17 L. Sturlese, Eckhart, Tauler, Suso. Filosofi e mistici nella Germania medievale (Firenze: Le Lettere, 2010), ch. VII ("Tauler e Bertoldo di Moosburg. I presupposti filosofici della dottrina del 'fondo dell'anima”"), p. 157-194, at p. 184-191; ch. IX ("Homo divinus. Il commento a Proclo di Bertoldo di Moosburg"), p. 237-257, at p. 244-246 (the texts are translated with few changes from the originals in L. Sturlese, Homo divinus. Philosophische Projeckte in Deutschland zwischen Meister Eckhart und Henrich Seuse [Stuttgart: Kohlhammer, 2007]); ch. XII ("Tauler im Kontext. Die philosophischen Voraussetzungen des 'Seelengrundes' in der Lehre des deutschen Neuplatonikers Berthold von Moosburg"), p. 169-197; ch. X ("Der Prokloskommentar Bertholds von Moosburg und die philosophischen Probleme der nacheckhartschen Zeit"), p. 137-154.

18 For the theory of providence in On Ten Doubts Concerning Providence, see for example the commentary and the doctrinal analysis in F. Brunner, W. Spoerri, "De decem dubitationibus circa providentiam, q. 3, 11-14. Commentaire philosophique par F. Brunner. Kritische 
Ex praemissis colligitur differentia providentiae et fati: tum quia [A] "providentia praeexistit fato et omnia quidem, quaecumque fiunt secundum fatum, multo prius a providentia fiunt" secundum auctorem De fato et providentia cap. 2. [B] Tum quia providentia est simpliciter omnium, fatum vere quorundam: "multa enim diffugiunt fatum, providentiam vero nihil" secundum auctorem ibidem. [C] Tum quia "providentia est fatum desuper gubernans, quod ipsa produxit et separavit ipsius epystasiam, id est superstationem, usque ad altero mobilia aut sortita in altero mobilibus subsistentiam", idem ubi supra. [D] Tum etiam quia proxima deo sunt exempta a fato, distantia vero subsunt. [E] Unde auctor ibidem 5 cap.: "Providentiam itaque non est tibi difficile videre, quam dicimus. Si enim fontem bonorum primum divinam ipsam causam determinans recte dicens, unde enim aliunde bona quam divinitus? Ita ut bonorum quidem, ait Plato, nullum alium causandum quam Deum. [F] Deinde omnibus superstantem intelligentialibusque et sensibilibus superiorem esse fato, et quae quidem sub fato entia et sub providentia perseverare, le conecti quidem a fato habentia, bonificari autem a providentia, ut conexio finem habeat bonum et providentia sic reductiva fati in se ipsam, quae autem rursum sub providentia non adhuc omnia indigere et fato, sed intelligentialia ab hoc (scilicet fato) exempta esse". Et bene infra: "Et propter haec omne quidem intellectualiter ens sub providentia perseverari solum, omne autem, quod corporaliter, sub necessitate. [G] Duo itaque regna rei intelligantur: haec quidem intellectualia, haec autem sensibilia, et regna duo duorum, providentiae quidem sursum intellectualiumque et sensibilium, fati autem deorsum sensibilium. [H] Et providentia differat a fato, qua differt Deus a divino quidem, sed participatione divino et non prime, quoniam et in aliis, ut vides, aliud quod prime, aliud quod secundum participationem velut lumen solis et quod in aere lumen, sed hic quidem prime, hoc autem propter illum (scilicet solem) lumen; et vita prime quidem in anima, secundario autem in corpore propter illam. Sic igitur providentia quidem Deus per se, fatum autem divina aliqua res et non Deus: dependet enim a providentia et velut imago est illius. Sicut enim providentia ad intellectualia entium, sic fatum ad sensibilia. [I] Regnat quidem haec (scilicet providentia) super intellectualia, hoc autem super sensibilia, et permutatim aiunt geometrae, et ut providentia ad fatum, sic

Exegetische-Bemerkungen von W. Spoerri", in Freiburger Zeitschrift für Philosophie und Theologie 24(1977), p. 112-164; for an overview of Proclus' theory of providence, see W. Beierwaltes, "Pronoia und Freiheit in der Philosophie des Proklos", in Freiburger Zeitschrift für Philosophie und Theologie 24(1977), p. 88-111. 
intellectualia ad sensibilia. Intellectualia autem prime sunt entia et ab his altera: et providentia ergo prime est, quod est, et ab hac dependet et fati ordo". Haec auctor. ${ }^{19}$

This text, which is quoted immediately after the citation from On the Consolation of Philosophy, Book IV, prose 6, provides Berthold with the conceptual tools he needs to rethink the relationship between providence and fate in more elaborate terms. Whereas Boethius considers fate to be the chain of causes by which the simple and eternal providence unfolds in space and time, this text sheds light on the existence of the two distinct, but interrelated, realms of providence and fate, analyzing their main characteristics. ${ }^{20}$

Berthold first points out that On Providence and Fate is in agreement with Boethius on several points: e.g., (A) providence preexists fate but (B) whereas nothing escapes providence, many things are not subject to fate. (C) Accordingly, "providence governs from above over fate" and "entrusts to it the authority as far as the bodies that are externally moved (or those things that first come to be in externally moved things)". (D) Finally, things close to God are exempt from fate. All of this confirms the preeminence that providence enjoys over fate, a point which was already clear in On the Consolation of Philosophy. Proclus' distinctive influence on Berthold's conception must be looked for in the rest of the quotation from On Providence and Fate.

19 Berthold of Moosburg, Expositio, 141B, p. 47, l. 78-p. 48, l. 109. The capital letters between square brackets have been introduced into the text to simplify references to the sections examined. For the texts in Proclus, see Proclus, De providentia et fato et eo quod in nobis ad Theodorum Mechanicum, in Tria opuscula (De providentia, libertate, malo), ed. H. Boese (Berlin: De Gruyter, 1960), c. 2, §3, p. 110, l. 6-p. 111, l. 8; c. 2, §4, p. 111, l. 4-7; c. 5, §13, p. 118, l. 1-p. 12o, l. 11 and l. 29-30; c. 5, §14, p. 120, l. 31-p. 122, l. 16. For literal quotations of On Providence, I have relied on Proclus, On Providence, trans. C. Steel (Ithaca, New York: Cornell University Press, 2007).

20 In spite of the undeniable analogies between lib. IV, prosa 6 of On the Consolation of Philosophy and Proclus' On Providence and Fate, the regna duo thesis constitutes a major difference between the two texts, which is peculiar to the Proclean treatise. On Boethius' relationship with Proclus and other Neoplatonists on the topic of fate, see H.R. Patch, "Fate in Boethius and the Neoplatonists", in Speculum 4(1929), p. 62-72; P. Courcelle, Les lettres grecques en Occident. De Macrobe à Cassiodore (Paris: De Boccard, 1948), p. 287-289, and J.C. Magee, "The Boethian Wheels of Fortune and Fate", in Mediaeval Studies 49(1987), p. 524-533. Courcelle and Magee offer criticisms of Patch's arguments. See also S. Gersh, Middle Platonism and Neoplatonism. The Latin Tradition, 2 vols (Notre Dame, Indiana: University of Notre Dame Press, 1986), vol. 2, p. 647-718; M. Belli, "Il centro e la circonferenza. Proclo, Boezio e Tommaso d'Aquino", in P. Totato, L. Valente (eds), Sphaera. Foma e immagine e metafora tra medioevo ed età moderna (Firenze: Olschki, 2012), p. 51-80, at p. $5^{1-62}$, and the literature quoted therein. 
As is clear from the previous paragraphs in Proclus' treatise, providence and fate act at two different levels: the former is the cause of the goods for those for whom it provides ("causam esse bonorum hiis quibus providetur"), whereas fate is "the cause of some connection between and sequence of the things that occur" ("causam [...] connexionis cuiusdam et consequentie hiis que generantur"). ${ }^{21}$ (F) As a consequence, things that depend on fate also fall under providence: "they have their interconnection from fate, but their orientation to the good comes from providence. Thus, the connection will have the good as its end and providence will order fate". (G) There are two realms (regna) of things intelligible and sensible. Providence rules over things intelligible and sensible, while fate only governs sensible things. Even though the two realms are hierarchically ordered, each of them is nonetheless autonomous, retaining its own laws. This means that the realm of fate, which is the world of nature, can be explained by its own laws without reference to any superior ontological level of reality. In this light, Berthold's keen interest in the issues related to celestial causality and, more generally, to the philosophy of nature, becomes clear. The realm of fate provides the theoretical framework for scientific research, at the same time granting a bottom-up perspective on the providence of God and the gods.

Finally, it should be noted that Berthold also adopts the typical Proclean distinction secundum causam and per participationem to clarify the difference between providence and fate. (E) Providence is said to be, as the divine cause, the first source of all goods. $(\mathrm{H})$ More precisely, providence stands in the same relationship to fate as the primary God does to what is divine by participation. (I) Moreover, since providence rules over intelligible beings whereas fate only rules over sensible beings, and since intelligible beings are primary beings (prime entia), providence is what it is primarily (prime est, quod est).

The Theologico-Metaphysical Approach: Providence and the Divine

Berthold's concept of providence is also indebted to another of Proclus' opuscules, Ten Doubts Concerning Providence (De decem dubitationibus circa providentiam). Indeed, in the propositum of Proposition 141, Berthold clarifies how providence is found in the divine, namely in the primary God and the

21 Proclus, De providentia, c. 3, §7, p. 113, l. 2-4. 
gods. The gods are the henads (unitates or bonitates), also defined as causae primordiales. ${ }^{22}$

According to Berthold, the absolutely Good is absolutely First and thus is not coordinated with the things that it causes. It exercises providence absolutely over all beings (providet omnibus simpliciter), and its providence transcends them. This is the condition of God in whom providence resides secundum causam. The gods, who are first in their own given genus, but not absolutely first, exercise providence over the subsequent members in their series. As in the case of God, their providence does not enter into relation with the things that they cause. Every god stands in relation to its own universe - its series just as the absolutely Good does to the entire Universe. ${ }^{23}$ The gods have providence per essentiam.

A long quotation from Proclus' Ten Doubts Concerning Providence confirms the difference between the providence secundum causam of the First

22 On the role and significance of the henads in Berthold, see L. Sturlese, "Einleitung", to Berthold of Moosburg, Expositio super Elementationem theologicam Procli. Propositiones 136-159, ed. F. Retucci (Hamburg: Meiner, 2007), p. ix-xv, at p. xi-xiii; A. Sannino, "Il Liber viginti quattuor philosophorum nella metafisica di Bertoldo di Moosburg", in A. Beccarisi, R. Imbach, P. Porro (eds), Per perscrutationem philosophicam. Neue Perspektiven der mittelalterlichen Forschung. Loris Sturlese zum 6o. Geburtstag gewidmet (Hamburg: Meiner, 2008), p. 252-272, at p. 252-267; E. Ludueña, "El politeísmo de Proclo en la Expositio de Bertoldo de Moosburg", in S. Filippi, M. Coria (eds.), La Identidad propia del Pensamiento Patrístico y Medieval. ¿Unidad y Pluralidad? (Rosario: Paideia Publicaciones, 2014), p. 393-403. On the function of the henads in Proclus' Elements of Theology, see E. Massa, "La deificazione nel commento di Bertoldo di Moosburg a Proclo, Elementatio theologica, 129. Edizione del testo e prime analisi”, in R. Lievens, E. Van Mingroot, W. Verbeke (eds), Pascua Mediaevalia. Studies voor Prof. Dr. J.M. De Smet (Leuven: Leuven University Press, 1983), p. 545-6o4, at p. 580-582; S. Gersh, "Proclus as theologian", in S. Gersh (ed.), Interpreting Proclus. From Antiquity to the Renaissance (Cambridge: Cambridge University Press, 2014), p. 80-107, at p. 92-97, with literature quoted at p. 93, n. 88 .

23 Berthold of Moosburg, Expositio, 141E, p. 49, l. 153-p. 50, l. 181: Primo modo simpliciter bonum, et hoc solum est prime simpliciter et per consequens non concluditur cum suis causatis nec intra ordinem partialem nec etiam totalem, sed est simpliciter exemptum ab omnibus simpliciter et per consequens non habet providentiam nisi exemptam, et sic providet omnibus simpliciter. Secundo modo prime, scilicet in genere, respectu videlicet determinati ordinis, sunt ipsi dii, quorum quilibet est monarcha respectu suae antarkiae, immo totius seyrae suae, id est omnium sub suae causalitatis ambitu contentorum, et per consequens est exemptus ab omnibus suis causatis, cum omne, quod prime causa, exaltatum sit ab effectu per 75. Et sic "omne divinum" et per essentiam et secundum causam "et providet secundis et ereptum est ab his, quibus providetur, neque providentia submittente suam immixtam et unialem excellentiam neque unione providentiam exterminante" per 122. [...] Sicut autem se habet simpliciter bonum ad totum universum simpliciter, sic se habet quilibet deus, qui est quaedam bonitas, ad suum universum. Et hoc de secundo. 
Principle, i.e. the primary Good, and the providence secundum essentiam of the gods. Berthold introduces a few slight changes to this text which involve a significant reinterpretation of Proclus' original intention. Whereas Proclus maintains that providence is the cause that makes everything that exists in the universe good ("propter providentie causam bonum habet"), Berthold affirms that it is the primary Good that makes things good ("propter prime bonum bonificantur"), implying that the primary Good is the first and originary source of providence. Moreover, Berthold specifies that those beings that receive by themselves (per se) their good from providence, without any other intermediary, are the gods and, especially, the primary God ("sicut dii et praecipue primo Deus"). ${ }^{24}$ In other words, God and the gods are the first agents, each in his own order, for the distribution of the good, which unfolds through the subordinate series and the lower members of each series. After this quotation, Berthold adds that providence is in the gods not only per essentiam, but also secundum participationem. Since they all exist within the order of God and receive his influence, the gods partake in his providence. ${ }^{25}$

In Proposition 141, Berthold refers twice to Proposition 120, another of the most cited propositions in the Tabula contentorum. Therefore, in order to better understand Berthold's views on the three modalities of providence - secundum causam, per essentiam, and per participationem - it is appropriate to turn to his discussion of Proposition 120 ("Omnis deus in sua existentia totis habet providere et primitus providere in diis"). In the propositum Berthold conceptualizes the three modes of providence: ${ }^{26}$

24 Berthold of Moosburg, Expositio, 141E, p. 5o, 1. 165-178. See Proclus, De decem dubitationibus circa providentiam, q. 3, §17, p. 30, l. 8-22.

25 Berthold of Moosburg, Expositio, 141F, p. 50, 1. 182-192: Sane, quia dii intra ordinem unialem et sint monarchae, ut dictum est, et antarkes et pro tanto, licet exempti sint a suis causatis sicut prime ens ab omnibus entibus, tamen omnes insimul accepti praeter prime Deum, cum concludantur intra ordinem, ut dictum est, qui ordo etiam sicut et omnis universitas est quoddam totum formale finitum specie et partibus. Et sic superior deus influit alteri submisso et bonitatem, inquantum gradatim bonitas in eis contrahitur, et etiam propriam intentionem, in qua est prime, cuius vestigium aliquale in sequentibus derelinquit. Et talis bonificatio sive provisio boni vel providentia, cum omnes sint coordinati, dicitur coordinata. Sicut autem dictum est de diis per essentiam, quod primorum est providentia respectu subsequentium coordinata, ita etiam se habet in omnibus diis secundum participationem [...].

26 Before conceptualizing the three ontological levels of the good in the propositum, Berthold had already distinguished the twofold status of the henads - per essentiam and secundum participationem - in the suppositum: Berthold of Moosburg, Expositio super Elementationem theologicam. Propositiones 108-135, ed. F. Retucci (Hamburg: Meiner, 2011), 120B, p. 93, l. 92-95: Deorum vero naturalium quidam sunt per essentiam tales, ut sunt superessentiales bonitates unialem ordinem integrantes, alii vero per participationem sunt huiusmodi, sicut prima inferiorum ordinum, puta infinitatum, substantiarum, vitarum, intellectuum et huiusmodi, sicut inferius apparebit. 
li 'bonum' dicitur tripliciter, quia "aut secundum causam, puta primum: etenim bonum illud et existentiae omnis causa et bonorum omnium ut unitatum" et sic etiam est universaliter omnium conservativum per providentiam propriae virtutis, "aut secundum existentiam, puta unusquisque deus unum et bonum existens" per 119 in commento, et istis convenit providentia per existentiam, sicut et bonitas, "aut secundum participationem, puta, quod in substantiis bonum, propter quod et unita est omnis substantia". ${ }^{27}$

By starting from the definition of providence as "the operation of the good bestowing what is appropriate upon each thing" ("operatio boni unicuique congrua largientis"), ${ }^{28}$ Berthold claims that the good is stated in three different ways. The Good secundum causam is the first Good, which is the cause of every being (existentiae omnis) and of all goods-unities. As such, the Good is the principle of the preservation of all things thanks to the providence of its power. The good per existentiam is predicated of the gods, as each god is good and one. Providence per existentiam resides in the gods. Finally, the good secundum participationem is predicated of substances in the sense that every substance is unified by its participation in the good.

The abovementioned text is indeed a literal quotation from Proclus' Ten Doubts Concerning Providence, punctuated by a few of Berthold's remarks, which make explicit the reference to providence which is merely implicit in the Proclean passage. A few lines below, after demonstrating that "one", being shared by all things, is the ratio providendi in general, Berthold again distinguishes three modes of "one" - secundum causam, per existentiam, and secundum participationem - on the basis of the same Proclean source. ${ }^{29}$

27 Berthold of Moosburg, Expositio, 120D, p. 99, 1. 269-276. See Proclus, De decem dubitationibus, q. 10, §63, p. 102, l. 7-p. 104, l. 12. Berthold of Moosburg, Expositio, 120I, p. 103, 1. 398-404: [...] prime providens est Deus, quia et prime bonum, quod non solum est verum simpliciter de prime Deo, sed etiam de diis, qui sunt prime bonum suorum ordinum. Alia autem post hos, quando secundum unum illocantur et divinae operantur. Cum igitur unum et bonum supersubstantialiter sit in ipsis diis et sic ipsorum essentia, necessario etiam ipsum providere primitus erit in eis et per eos in omnibus, quibus participative convenit providere, sicut et bonum est in eis per participationem.

28 Berthold of Moosburg, Expositio, 120D, p. 98, l. 26o.

29 Berthold of Moosburg, Expositio, 120H, p. 102, 1. 374-381. See Flasch, "Einleitung", p. xiiixvii, xxi-xxiii, concerning the priority of the Good over the One. For this reason, Imbach considers it not inappropriate to refer to Berthold's theological philosophy (scientia divina) as agatho-theology. See Imbach, "Au-delà de la métaphysique", p. 388, n. 63 . J.A. Aertsen, "Ontology and Henology in Medieval Philosophy (Thomas Aquinas, Master Eckhart and Berthold of Moosburg)", in E.P. Bos, P.A. Meijer (eds), On Proclus and His Influence in Medieval Philosophy (Leiden / New York / Köln: Brill, 1992), p. 120-140, at p. 125, n. 24, disagrees with Flasch on this point. 
Once it has been made clear that there are three levels of providence, but that the providential order ultimately must be reduced to the primary God, in whom providence secundum causam resides, the question arises as to why God, who can govern the universe on his own without any help, delegates his providence to the secondary gods. In this case, Berthold has recourse to the same quotation from Ulrich of Strassburg's De summo bono II.5.18 which he also cites in Proposition 141. ${ }^{30}$ Adopting what we can call a principle of plenitude, Berthold argues that God accomplishes through secondary causes which are the primordial causes - all that he could have done by himself and could have governed through his providence, so that the universe, which has received from him all the possible degrees of divine goodness, may not be deprived of the dignity of causality and the opportunity to cooperate in his divine operation. The secondary causes are arranged according to the twofold mode of providence theorized by Augustine's De Genesi ad litteram.

Circa tertium sciendum, quod, licet prime bonum super omnia superbenedictus Deus per se principaliter omnia efficiat et per providentiam gubernet, tamen, ut dignitas causalitatis et divinae cooperationis, quae est divinissimum operum, non deesset universo, cui communicati sunt omnes gradus divinae bonitatis possibiles existere, operatur etiam per secundas causas a se, scilicet per primordiales. Et istae sunt ordinatae dupliciter secundum duplicem modum providentiae, quae distinguit Augustinus viII Hexaemeron sui dicens, quod "gemina operatio providentiae invenitur, partim naturalis, partim voluntaria”. Secundum primum actum providentiae est ordo naturalis causarum, qui in hoc volumine exprimitur, quibus omnibus supereminent ipsae primordiales causae, quas auctor vocat deos. ${ }^{31}$

The meaning of natural providence changes between Proposition 141 and Proposition 120. We see in this passage from $120 \mathrm{E}$ that Berthold does not understand the notion in a physicalist sense. This is all the more surprising given that, as we already know, Ulrich's De summo bono II.5.18 is the seminal source for Berthold's physical interpretation of natural providence. Yet, if we compare the abovementioned passage with its source in the De summo bono, we will notice a few interesting differences:

30 See above, footnote 14.

31 Berthold of Moosburg, Expositio, 120E, p. 10o, l. 295-305. 
Ad horum ergo intellectum consideremus primo, quid hoc nomine significetur. Deus omnia, quae causat, per providentiam causat eo, quod ipse operatur per intellectum et artem. Et quamvis per se principaliter omnia efficiat, tamen, ut dignitas causalitatis et divinae cooperationis non deesset universo, cui communicatae sunt omnes divinae bonitates naturaliter communicabiles, operatur etiam per secundas causas. Et illae sunt ordinatae dupliciter secundum duplicem modum providentiae. Dicit enim Augustinus viII libro Super Genesim: "Gemina operatio providentiae reperitur: partim naturalis, per quam dat lignis et herbis incrementum, partim voluntaria per operationem angelorum et hominum". Secundum primum actum providentiae est ordo naturalis causarum, quem philosophi determinant, scilicet quod primo sunt causae universales, scilicet caelestia et motus eorum, et sub illis sunt causae particulares. ${ }^{32}$

What are only secondary causes in the De summo bono, become the primordial causes, i.e. the gods, in the commentary on the Elementatio theologica. Whereas according to Ulrich the chain of physical causes, from the celestial spheres down to the particular causes, constitutes the order of causes of natural providence determined by philosophers - the foremost among whom is Boethius - Berthold refers to the natural order of causes which is expressed in this volume (in hoc volumine exprimitur), namely in the Elements of Theology. Therefore, Berthold is clearly reinterpreting Ulrich's notion of the connection of physical causes in terms of the order of theologico-metaphysical causes, the most perfect and highest of which are the primordial causes, namely the gods-henads. Significantly, while Ulrich also cites the first examples of natural providence mentioned by Augustine - examples based on the natural world (the growing of trees and herbs), here Berthold leaves them out.

Overall, then, the metaphysical reinterpretation of Ulrich's text runs counter to Proposition 141, where Berthold regards natural providence as fate and theorizes the existence of the realm of fate. Far from excluding each other, Berthold's two different conceptions of natural providence indicate the existence of two different approaches to providence in the Expositio.

In Proposition 122 ("Omne divinum et providet secundis et ereptum est ab his, quibus providetur, neque providentia submittente suam immixtam et unialem excellentiam neque unione providentiam exterminante"), which is also widely quoted in the Tabula, Berthold shifts his focus to the transcendence of both the general providence of the primary Good and the special providence of the gods. He argues that since it pre-contains the lower members in a nobler 
way that they exist in themselves, all that is first in every essentially ordered universe is the universal cause exercising providence over all those that are posterior. ${ }^{33}$ Moreover, that which is essentially divine (divinum per essentiam) is said to be the essence of the things for which it provides, while these things participate in it according to their capacity. However, that which is essentially divine is exempt from them (exemptum a provisivis), for were it not transcendent, its causality would no longer be universal. ${ }^{34}$

The transcendence of all that is divine - both secundum causam and secundum essentiam - relative to its own effects is due to its absolute and excellent unity. ${ }^{35}$ From Dionysius the ps.-Aeropagite Berthold derives the analogy between goodness and the sun, which nicely fits his attempt to describe the transcendence of providence. He maintains that just as the sunlight shines everywhere, yet the sun keeps unchanged the purity and perpetuity of its substance, remaining what it is, so the operation of providence reaches everything, while at the same time transcending everything.

Talis autem extensionis actus providendi generalitate sua ad omnia et nihilominus ereptionis eius ab omnibus exemplum satis aptum invenimus in nostro sole magno, qui est "totus splendens et superlucens" [...] sed per ipsum esse "illuminat omnia, quaecumque participare ipso possunt, et superextentum habet lumen ad omnem extendens visibilem mundum splendores propriorum radiorum et sursum et deorsum". "Et nihil est visibilium, ad quod non pertingat secundum magnitudinem excedentem splendorem proprii luminis". Et licet ipse sol sic sit in inferioribus istis generabilibus et corruptibilibus, quae "et movet ad vitam et nutrit et auget et perficit et mundat et renovat", tamen nihilominus non recedit a puritate et perpetuitate suae substantiae manens hoc, quod est. ${ }^{36}$

33 Berthold of Moosburg, Expositio, 122A, p. 116, 1. 67-69: Omne autem primum omnis universitatis essentialiter ordinatae praehabet omnia submissa nobiliori modo, quam sint in se ipsis, et sic est causa universaliter providens omnibus, quae sunt post ipsum.

34 Berthold of Moosburg, Expositio, 122B, p. 117, l. 88-91: [...] sequitur ipsum esse essentiam omnium provisorum, quae tamen essentia est in unoquoque provisorum, secundum quod potest ea participare ex propria analogia. Item, quod sit exemptum a provisivis, quia, si esset inter provisa, non provideret omnibus universaliter [...].

35 Berthold of Moosburg, Expositio, 122L, p. 121, l. 266-p. 122, l. 268: sed ratione unitatis est ereptum ab omnibus, quibus providetur, et in se ipso mansivum in sua unionali excellentia.

36 See Berthold of Moosburg, Expositio, 122I, p. 120, l. 220-p. 121, l. 232. See Dionysius ps.Areopagita, De divinis nominibus, ed. B.R. Suchla (Berlin / New York: De Gruyter, 199o), 4.4, p. 147 , l. 11-p. 148, l. 5 . 
The realm of fate is the domain of corporeal and sensible things, of physical phenomena, of knowledge based on sense-perception: simply put, it is the world of nature.

In order to understand what exactly Berthold means by the realm of fate and what he considers to be the relationship between fate and providence, I turn to Proposition 34 ("Omne, quod secundum naturam convertitur, ad id facit conversionem, a quo et processum propriae subsistentiae habet"), which does not explicitly deal with providence, but rather with nature. In the suppositum, while illustrating the several meanings of the word natura, Berthold quotes a long text from the Hermetic De VI rerum principiis. From this text he derives the idea of nature as a universal and special power (vigor) which first resides in the celestial sphere and operates in inferior realities by stimulating their qualities to develop. ${ }^{37}$ Nature originates from ratio, the law of the stars (lex astrorum), which is the uniform and perpetual disposition of the celestial motions. With this disposition originates the machine of the world (mundi machinam), by which the world and its components are harmoniously ruled (benigna amicitiae pace). ${ }^{38}$

37 Berthold of Moosburg, Expositio super Elementationem theologicam. Propositiones 14-34, eds L. Sturlese, M.R. Pagnoni-Sturlese, B. Mojsisch (Hamburg: Meiner, 1986), 34A, p. 222, 1. 67-89: natura est vigor quidam universalis et specialis ex causa et ratione nascens, primum caelo innascens, in universis et singulis quadrupartitus, qualificatus non qualificans et quantificatus non quantificans, differentes qualitates successive diffundens. [...] Natura vero nata qualitates in singulis differentes non qualificando, sed operando diffundit, id est qualitates excitando exerit. Simile potest dici de quantitate, quod eam successive dicitur diffundere, ut unaquaeque res ab alia in suo genere nascatur. See Hermes Latinus, Liber Hermetis Mercurii Triplicis de VI rerum principiis, ed. T. Silverstein, in Archives d'histoire doctrinale et littéraire du Moyen Âge 22(1955), p. 217-302, at p. 248-249. For an analysis of Berthold's Hermetic conception of nature, see A. Sannino, "Il concetto ermetico di natura in Bertoldo di Moosburg", in P. Lucentini, I. Parri, V. Perrone Compagni (eds), Hermetism from Late Antiquity to Humanism. La tradizione ermetica dal mondo tardo-antico all'Umanesimo = Atti del Convegno internazionale di studi, Napoli 20-24 novembre 2001 (Turnhout: Brepols, 2003), p. 203-221. For inspiring remarks on the theory of nature by Dietrich of Freiberg and Berthold, see M.R. Pagnoni-Sturlese, "Filosofia della natura e filosofia dell'intelletto in Teodorico di Freiberg e Bertoldo di Moosburg”, in K. Flasch (ed.), Von Meister Dietrich zu Meister Eckhart (Hamburg: Meiner, 1984), p. 115-127.

38 Berthold of Moosburg, Expositio, 34A, p. 221, 1. 50-54: Ratio est vis quaedam a causa procedens, cuncta a principio ordinans. Haec lex astrorum dicitur, quae est aequa et perpetua motuum eorum dispositio, quae mundi machinam efficit et moderatur, per quam mundus et mundana nulla coactione, sed benigna amicitiae pace reguntur. See Hermes Latinus, Liber de VI rerum principiis, p. 248. 
In light of this Hermetic text and the other sources quoted by Berthold (Avicebron and Isaac Israeli), it can be argued that nature is bipartite, being subdivided into a superior operating nature (natura superior operativa), which consists in the quality of the celestial bodies, and an inferior nature (natura inferior), which consists in the elemental qualities acted upon by the motions of the celestial spheres. ${ }^{39}$

This perspective is in accord with the special attention Berthold devotes to issues related to celestial causality and their investigation, which may at first appear out of place in a commentary on the theologico-metaphysical summa of the Neoplatonic tradition. By way of example, I refer only to a long quotation from a certain "diligens motuum astrorum investigator et calculator, frater Arnoldus dictus Luscus" (the one-eyed brother Arnoldus).$^{40}$ According to Berthold, Arnoldus is the author of a work entitled De periodis motuum et mobilium caelestium, which was dedicated to calculating the periods of the celestial bodies. From this work, Berthold quotes the scientist as saying that the calculation of the Great Year (the famous and feared Magnus Annus) is incomprehensible to the human intellect, being known only to God and to

39 Berthold of Moosburg, Expositio, 34A, p. 222, l. 90-p. 223, l. 112. On Hermes' presence in Berthold, see L. Sturlese, "Proclo ed Ermente in Germania da Alberto Magno a Bertoldo di Moosburg. Per una prospettiva di ricerca sulla cultura filosofica tedesca nel secolo delle sue origini (1250-1350)", in K. Flasch (ed.), Von Meister Dietrich zu Meister Eckhart, p. 22-33, at p. 28-30; A. Sannino, "Berthold of Moosburg's Hermetic Sources", in Journal of the Warburg and Courtauld Institutes 63(2000), p. 243-258; A. Palazzo, "La ricezione di un passo ermetico (Asclepius 8) nel tardo medioevo. Ulrico di Strasburgo, Pietro di Tarantasia, Riccardo di Mediavilla, Bertoldo di Moosburg e Dionigi il Certosino", in T. Iremadze, T. Tskhadadze, G. Kheoshvili (eds), Philosophy, Theology, Culture. Problems and Perspectives. Jubilee Volume Dedicated to the 75th Anniversary of Guram Tevzadze (Tbilisi: Publishing House "Nekeri" / Publishing House "Arche", 2007), p. 104-125, at p. 113-121.

40 Th. Kaeppeli, Scriptores Ordinis Praedicatorum Medii Aevi, 4 vols (Roma: Istituto Storico Domenicano, 1970-1993), vol. 1, p. 133, only includes Arnoldus in his catalogue without being able to provide any biographical detail. I. Draelants, "La transmission du De animalibus d'Aristote dans le De floribus rerum naturalium d'Arnoldus Saxo", in C. Steel, G. Guldentops, P. Beullens (eds), Aristotle's Animals in the Middle Ages and Renaissance (Leuven: Leuven University Press, 1999), p. 126-158, at p. 132, n. 21, conjectures that Arnoldus is in fact the same person as Arnold of Saxony, a German Dominican active in the 13th century, and the author of the encyclopaedia entitled De floribus rerum naturalium. According to Draelants, the hypothesis could be supported provided that Arnold is demonstrated to be the author of the astronomical and astrological content of Ms Basel, Universitätsbibliothek, O.vı.4, which bears evident resemblances to Arnold's authentic works. 
whomever he will disclose it; moreover, Berthold copies the table calculating the positions of the celestial bodies over the Great Year. ${ }^{41}$

The importance of astronomy and astrology also lies in their practical usefulness. Berthold claims in the prologue that these sciences enable man to govern the sensible world, which is the realm of fate. This is due to the fact that among all philosophers, only astrologers were divinely given by celestial decrees the ability to investigate and grasp future events by observing the first natural, essential, and eternal causes. ${ }^{42}$

Since it is ruled by celestial causality, inferior nature is intrinsically ordered. Based on this assumption, Berthold cannot doubt the purposefulness of the work of nature or its finalism ("secundo de ipsius naturae, prout hic sumitur, in operando finis praeconceptione et totius operis sui in finem directione"). Indeed, he contends that the thesis that nature is a force (vis) moving without any rational design leads to a series of doctrinal mistakes, such as necessitarianism, the absence of a maker of nature, chance, the denial of natural finalism. Against these erroneous positions, Berthold argues that nature is ruled by a superior rational principle, adducing a number of authorities in support of this view.

From Book XII of Averroes' Commentary on the Metaphysics Berthold quotes the renowned dictum stating that "even nature does not know, nonetheless it works in a perfect and orderly way, somehow recalled by nobler active virtues, which are called intelligences". ${ }^{43}$ The rationality of the natural mechanism is

41 Berthold of Moosburg, Expositio super Elementationem theologicam. Propositiones 184-211, ed. L. Sturlese (Hamburg: Meiner, 2014), 198E, p. 147, l. 151-p. 148, l. 196. On the theory of the Magnus Annus, see G. De Callataÿ, Annus Platonicus. A Study of World Cycles in Greek, Latin and Arabic Sources (Louvain-la-Neuve: Université Catholique de Louvain / Institut Orientaliste, 1996). One should note that Proclus also displays a keen interest in physical investigation and astronomy, as attested by his several works in both these fields. However, the Platonic astronomy pursued by Proclus searches for the hidden causes of phenomena and is different from "scientific" investigation based on observation of celestial phenomena and the formulation of artificial hypotheses. See A.-Ph. Segonds, "Philosophie et astronomie chez Proclus", in G. Boss, G. Seel (eds), Proclus et son influence. Actes du Colloque de Neuchâtel, juin 1985 (Zürich: Éditions du Grand Midi, 1987), p. 159-177.

42 Berthold of Moosburg, Expositio, Prologus 16, p. 24, 1. 636-641: Quod autem per eas et specialiter astronomiam et astrologiam homo mundi sensibilis vocetur proprie gubernator, apparet. Tum quia astrologis solis inter omnes philosophantes divino munere communicae tum est decretorum caelestium ex consideratione causarum naturalium primarum per se et essentialium ac sempiternarum in futurorum eventibus scrutatores esse et conscios [...].

43 Berthold of Moosburg, Expositio, 34B, p. 224, 1. 148-151: Nam secundum Averroem super XI Metaphysicae cap. 6 "natura", "quamvis non intelligat" nec rationem habeat, "facit" tamen "perfecte et ordinate, quasi esset rememorata ex virtutibus agentibus nobilioribus ea, quae dicuntur intelligentiae". See Averroes, Metaphysica, in Aristotelis Opera cum Averrois 
evident in the balance (mensura) between the heat of stars and that of generated things, a balance that depends on the divine intellectual art.

Divine providence (divina sollicitudo) is the cause of the rational government of nature: ${ }^{44}$ all beings and natural processes exhibit regularities because they originate from the divine mind, as is made clear in On the Consolation of Philosophy, Book IV, prose 6. Significantly, in this case Berthold only quotes the beginning of Boethius' passage, the part that relates to physical processes, while omitting the rest of prose 6: "omnium generatio rerum cunctusque mutabilium naturarum progressus et, quidquid aliquo movetur modo, causas, ordinem, formas ex divinae mentis stabilitate sortitur". 45

Cicero's De natura deorum confirms that the orderliness of natural processes indicates that nature is governed rationally by the divine art.

Istud nihilominus regimen rationis inesse naturae ab arte prima, videlicet divina, per artes, quae sub illa sunt, manifestum est per operationes ipsius naturae in naturalibus, secundum quod eleganter declarat Cicero ubi supra libro II capitulis 10, 11, 12 tam in animalibus quam in terrae nascentibus, tam in caelestibus quam terrestribus, ut breviter recolligam, quae "natura mentis et rationis expers" efficere non potuit, utpote mundi stabilitio, apertissima eiusdem cohaesio, partium libratio, circularis colligatio, stellarum ordinatio, motuum proportio, alimenti a terrae nascentibus attractio, arborum erectio, mutua invicem complexio, animantium in suo genere distinctio, ciborum variorum electio, medicinarum quaesitio, sollertiarum et artium ostensio, marium et feminarum ad perpetuam generis conservationem distinctio, partium corporis ad procreandum concipiendumque aptatio, ad generandum mutua desideriorum excitatio, sine magistro duce mammarum appetitio, appetitarum inventio, ad custodiendum procreata dilectio. His et consimilibus manifestum est "mente consilioque divino omnia in hoc mundo ad salutem hominum conservationemque administrari mirabiliter" secundum eundem. Ex quibus etiam concluditur nihil eorum esse fortuitum, immo

Commentariis, 8 vols (Venezia: Junta, 1562-1574), vol. 8, lib. XII, comm. 52, f. 305rD-E. Interestingly, the same dictum is quoted several times by Eckhart indirectly through Thomas Aquinas' works. See A. Palazzo, "Eckhart's Islamic and Jewish Sources. Avicenna, Avicebron, and Averroes", in J. Hackett (ed.), A Companion to Meister Eckhart (Leiden / Boston: Brill, 2013), p. 253-298, at p. 286-288.

44 Berthold of Moosburg, Expositio, 34B, p. 224, l. 154.

45 Berthold of Moosburg, Expositio, 34B, p. 224, l. 161-p. 225, 1. 164. See Boethius, De consolatione philosophiae, lib. IV, prosa 6, §7, p. 122, 1. 20-23. 
haec omnia esse opera providae sollertisque naturae, secundum quod dicit in eodem. ${ }^{46}$

Above all, one is persuaded that the world is ruled by intelligent reason by considering the uniformity of celestial motions, as these are the origin for the regularity of physical events, experienced in the inferior region.

[...] unde, sicut dicit idem ubi iam supra, ex certis caeli motibus, ex ratis astrorum ordinibus, ex sphaerarum revolutionibus, quae non nisi vera ratione fieri possunt, convincitur mundum regi non casu, sed ratione, sicut ipse idem manifestat in eodem per pulchram contemplationem visibilium usque ad 11 capitulum. ${ }^{47}$

Aristotle's Physica argues that even creatures such as monsters, usually considered to be mistakes of nature, demonstrate the teleologism of nature: they do not occur because natural events lack direction, but as a result of a material contrariety, which prevents the natural agent from introducing the intended form into matter. ${ }^{48}$

In other words, Berthold is persuaded that contemplation of the order and beauty of nature, as well as the scientific study of physical and astronomical processes, offers access to providence, access based on the effects of providence on the inferior world. ${ }^{49}$ This a posteriori demonstration, which leads to

46 Berthold of Moosburg, Expositio, 34B, p. 225, l. 170-188. As for Cicero's De natura deorum, see the passages registered ad lin. by Berthold's editors.

47 Berthold of Moosburg, Expositio, 34B, p. 226, l. 205-209.

48 Berthold of Moosburg, Expositio, 34B, p. 227, 1. 237-245: Ceterum id ipsum ostendit peccatum et error, quod accidit tam in natura quam in arte, quia omne agens, circa cuius actum contingit peccatum et error, agit propter finem, sed non invenit suam intentionem propter impedimentum; in quibus enim peccatur, alterius gratia agitur; natura autem est ratio agendi, in qua accidit error et peccatum, sicut apparet in monstris propter indispositionem ex parte materiae, ob quam efficiens non inducit formam intentam in materiam, sicut in semine, quando corrumpitur, agens non inducit formam intentam, quia prius necesse est esse semen, quam sit animal, et multas in eo praecedere alterationes.

49 He uses the same lines of reasoning when it comes to the issue of the providence exercised by each god, for he maintains that it is possible to intuit the existence of a superior rationality from the order (Berthold of Moosburg, Expositio, 120E, p. 96, l. 195: ad ordinem; p. 96, 1. 197-198: per contrariorum in unitatem concordantiam; p. 97, 1. 223-224: in ordine secundum gradum sibi debitum), the beauty (p. 97, 1. 212-222: ex specie), and the effects it has created. In this context, a preeminent role must be credited to Cicero's De natura deorum, often cited indirectly through Thomas of York's Sapientiale. On this, see F. Retucci, "Magister Thomas Anglicus Minor. Tommaso di York fonte dell'Expositio di Bertoldo di Moosburg", in Quaderni di Noctua. La tradizione filosofica dall'antico al moderno 5(2019), p. 1-41, as well as Retucci's contribution in this volume. One finds an intriguing hint 
knowing the existence of the divine intelligence and his providential activity, does not conflict with but rather complements the metaphysical approach, which focuses on providence as the distribution of the good from the primary God secundum causam through the divine per essentiam and per participationem and down to the whole of reality.

It has been argued that, in Berthold's view, philosophical enquiry consists in both knowledge of God and the study of nature. ${ }^{50}$ It must, however, be emphasized that these are not two separated fields of research, but two levels of one and the same "oblique" motion, the type of philosophical investigation adopted by Proclus in the Elements of Theology. By progressing per ratiocinationem from known to unknown things, from sensible to intelligible beings, the philosopher eventually comes to know the highest Good. He ascends to "the theological" contemplation of the One by considering the works of creation, the government of creatures, and the harmony of contrasting things.

[...] per motum obliquum, qui proprius erat philosophorum et erat per laboriosam investigationem primi omnium existentium principii dividendo, definiendo, communibus principiis utendo, a notis ad ignota per ratiocinationem progrediendo, a sensibilibus ad intelligibilia ascendendo et inter intelligibilia ab uno in aliud tendendo, quousque ad simpliciter ultimum perveniatur, ascenderit ipse Proclus in summi boni notitiam, apparet in praesenti libro, ubi in excelsum maximum ascendit per operum conditionem, conditorum gubernationem et contrariorum conciliationem. ${ }^{51}$

In sum, by perceiving the effects of divine providence on the order of physical events and the regularity of celestial phenomena, a human being can start a process of cognitive improvement that will culminate in a unifying grasp of everything (secundum unum omnium), as he attains the cognitio providentionalis proper to the primary One. ${ }^{52}$

at Thomas of York's conception of the beauty of the cosmos in U. Eco, Arte e bellezza nell'estetica medievale (Milano: La nave di Teseo, 2016), p. 44, n. 1.

50 U.R. Jeck, "Die hermetische Theorie des Mikrokosmos in der Metaphysik Alberts des Grossen und im Prokloskommentar des Berthold von Moosburg", in Patristica et Mediaevalia 20(1999), p. 3-18, at p. 7 .

$5^{1} \quad$ Berthold of Moosburg, Expositio, Expositio tituli D, p. 40, l. 110-117.

52 On cognitio providentionalis, see Berthold of Moosburg, Expositio, 134D-E, p. 215, l. 61-p. 217, l. 104. 
Berthold's belief in the rational governance of nature, emphasis on the order of the machina mundi, and admiration for the harmony of nature, and so on, were not merely traditional and stereotypical motifs derived from his sources that he wearily repeated. On the contrary, Berthold was truly fascinated by the world of nature. From the scanty information at our disposal, we know that he owned and annotated manuscripts containing works of scientific content (Ptolemy's Almagest and Macrobius' Commentary on the Dream of Scipio) and Albert the Great's autographs (De animalibus, a part of Physica, De caelo, De generatione et corruptione, De natura loci and De causis proprieta-

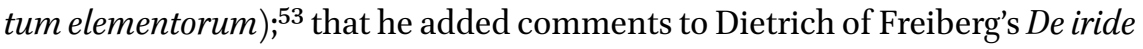
and Aristotle's Meteora; and that he wrote a now lost treatise De polo iridis. ${ }^{54}$ Moreover, his Exposition on the Elements of Theology discusses several issues in natural philosophy (light, ${ }^{55}$ time, movement, celestial periods, etc. ${ }^{56}$ ) and quotes large extracts from several scientific sources (e.g. Ptolemy, Thebit ben Chorat, Alhazen, Alfred the Englishman, etc.). All of this contributes to the picture of a scholar with prominent scientific interests, a thinker dominated by Wissenschaftspathos. ${ }^{57}$

By delineating a two-layered structure of reality, the regna duo theory provides the philosophical background for Berthold's scientific interest and research. Fate is the principle behind the connection of cause and effect; it is what binds the dispersed multiplicity of sensible phenomena together, giving rise to an orderly and knowable world, to nature itself. Behind - and above the regularity of natural processes and the uniform periodicities of celestial bodies moved by celestial souls, human reason recognizes a superior and

53 On the Berthold's "library", see Sturlese, "Introduzione", p. xix-lix.

54 L. Sturlese, "Note di Bertoldo di Moosburg O.P., scienziato e filosofo", in Freiburger Zeitschrift für Philosophie und Theologie 32(1985), p. 249-259; According to early-modern sources, he also wrote several works on astronomy: Albert de Castello, Brevis et compendiosa Cronica ordinis Praedicatorum, in R. Creytens, "Les écrivains dominicains dans la chronique d'Albert de Castello", in Archivum Fratrum Praedicatorum 30(1960), p. 227313, at p. 283 (the Chronica is found at p. 26o-291); B. Faes de Mottoni, "Il commento di Bertoldo di Moosburg all'Elementatio theologica di Proclo. Edizione delle proposizioni riguardanti il tempo e l'eternità", in Studi medievali 12(1971), p. 417-461, at p. 419-420.

See e.g. B. Faes de Mottoni, "Il problema della luce nel commento di Bertoldo di Moosburg all'Elementatio theologica di Proclo", in Studi medievali 16(1975), p. 325-352.

56 Due to space limitations I could not examine Propositions 198-200, dedicated to movement, animation and cosmology and largely based on natural-philosophical sources (e.g., Proclus' Elementatio physica, Aristotle's physical writings, the Timaeus, etc.).

Flasch, "Einleitung", p. xix. 
divine intelligence. At the physical level, the causal operation of divine providence brings forth the arrangement of natural events according to regular laws of development.

Despite its importance, the role of fate - and the world of nature more generally - has largely been underestimated by scholarship, leaving the Augustinian doctrine of twofold providence as the main focus for scholarship on Berthold's theory of providence. Yet it is precisely this relationship between the regna duo, between providence and fate, that deserves more attention if Berthold's theory is to be fully understood in itself and in the context of the debate on providence that took place among German Dominicans between the mid-13th century and the third quarter of the 14th century.

This new interpretive approach, which emphasizes the astronomicalphysical processes within Berthold's metaphysical project, also unveils a tension that seems inherent in the concept of natural providence and that has until now remained undetected. In the Exposition on the Elements of Theology, we find two different understandings of natural providence. Often, as in the Expositio tituli, Berthold interprets natural providence in a theologicometaphysical way as the procession of goodness which, originating with the primary God secundum causam, is per essentiam and per participationem in the divine realities. Sometimes, however, Berthold adopts a physical approach, consonant with Augustine's passage in the De Genesi ad litteram, and considers natural providence to be the order of natural phenomena, seeing in this order the proof of the existence of a superior ruler.

\section{Bibliography}

\section{Manuscripts}

Basel, Universitätsbibliothek, O.vI.4.

\section{Primary Sources}

Albert de Castello, Brevis et compendiosa Cronica ordinis Praedicatorum, in R. Creytens, "Les écrivains dominicains dans la chronique d'Albert de Castello", in Archivum Fratrum Praedicatorum 30(1960), p. 227-313.

Albert the Great, Summa theologiae. Pars prima, ed. A. Borgnet, Opera omnia, vol. 31, Paris, Vivès, 1894.

Augustine, De Genesi ad litteram libri duodecim, ed. J. Zycha, Praha / Wien / Leipzig, Tempsky, 1894.

Averroes, Metaphysica, in Aristotelis Opera cum Averrois Commentariis, 8 vols, Venice, Junta, 1562-1574. 
Berthold of Moosburg, Expositio super Elementationem theologicam Procli. 184-211. De animabus, ed. L. Sturlese, Roma, Edizioni di Storia e Letteratura, 1974.

Berthold of Moosburg, Expositio super Elementationem theologicam. Prologus. Propositiones 1-13, eds. M.R. Pagnoni-Sturlese, L. Sturlese, Hamburg, Meiner, 1984.

Berthold of Moosburg, Expositio super Elementationem theologicam. Propositiones 14-34, eds L. Sturlese, M.R. Pagnoni-Sturlese, B. Mojsisch, Hamburg, Meiner, 1986.

Berthold of Moosburg, Expositio super Elementationem theologicam. Propositiones 136159, ed. F. Retucci, Hamburg, Meiner, 2007.

Berthold of Moosburg, Expositio super Elementationem theologicam. Propositiones 108135, ed. F. Retucci, Hamburg, Meiner, 2011.

Berthold of Moosburg, Expositio super Elementationem theologicam. Propositiones 184211, ed. L. Sturlese, Hamburg, Meiner, 2014.

Berthold of Moosburg, Tabula contentorum in Expositione super Elementationem theologicam Procli, ed. A. Beccarisi, Pisa, Scuola Normale Superiore, 2000.

Boethius, De consolatione philosophiae. Opuscula theologica, ed. C. Moreschini, München / Leipzig, Saur, 2000.

Dietrich of Freiberg, De subiecto theologiae, ed. L. Sturlese, in Opera omnia, vol. 3. Schriften zur Naturphilosophie und Metaphysik, eds J.-D. Cavigioli et al., Hamburg, Meiner, 1983, p. 279-282.

Dionysius ps.-Areopagita, De divinis nominibus, ed. B.R. Suchla, Berlin / New York, De Gruyter, 1990.

Hermes Latinus, Liber Hermetis Mercurii Triplicis de VI rerum principiis, ed. T. Silverstein, in Archives d'histoire doctrinale et littéraire du Moyen Âge 22(1955), p. 217-302.

Proclus, Tria opuscula (De providentia, libertate, malo), ed. H. Boese, Berlin, De Gruyter, 196o.

Proclus, On Providence, trans. C. Steel, Ithaca, New York, Cornell University Press, 2007. Ulrich of Strassburg, De summo bono. Liber 2, Tractatus 5-6, ed. A. Beccarisi, Hamburg, Meiner, 2007.

\section{Secondary Sources}

Aertsen, J.A., "Ontology and Henology in Medieval Philosophy (Thomas Aquinas, Master Eckhart and Berthold of Moosburg)", in E.P. Bos, P.A. Meijer (eds), On Proclus and His Influence in Medieval Philosophy, Leiden / New York / Köln, Brill, 1992, p. 120-140.

Beccarisi, A., "La scientia divina dei filosofi nel De summo bono di Ulrico di Strasburgo", in Rivista di Storia della filosofia 61(2006), p. 137-163.

Beccarisi, A., "Einleitung", in Ulrich of Strassburg, De summo bono. Liber 2, Tractatus 5-6, ed. A. Beccarisi, Hamburg, Meiner, 2007, p. vii-xx.

Beierwaltes, W., "Pronoia und Freiheit in der Philosophie des Proklos", in Freiburger Zeitschrift für Philosophie und Theologie 24(1977), p. 88-111. 
Belli, M., "Il centro e la circonferenza. Proclo, Boezio e Tommaso d'Aquino", in P. Totato, L. Valente (eds), Sphaera. Foma e immagine e metafora tra medioevo ed età moderna, Firenze, Olschki, 2012, p. 51-8o.

Brunner, F., Spoerri, W., "De decem dubitationibus circa providentiam, q. 3, 11-14. Commentaire philosophique par F. Brunner. Kritische Exegetische-Bemerkungen von W. Spoerri", in Freiburger Zeitschrift für Philosophie und Theologie 24(1977), p. $112-164$.

Courcelle, P., Les lettres grecques en Occident. De Macrobe à Cassiodore, Paris, De Boccard, 1948.

De Callataÿ, G., Annus Platonicus. A Study of World Cycles in Greek, Latin and Arabic Sources, Louvain-la-Neuve, Université Catholique de Louvain / Institut Orientaliste, 1996.

Draelants, I., "La transmission du De animalibus d'Aristote dans le De floribus rerum naturalium d'Arnoldus Saxo", in C. Steel, G. Guldentops, P. Beullens (eds), Aristotle's Animals in the Middle Ages and Renaissance, Leuven, Leuven University Press, 1999, p. $126-158$.

Eckert, W., "Berthold von Moosburg O.P. Ein Vertreter der Einheitsmetaphysik im Spätmittelalter", in Philosophisches Jahrbuch 65(1957), p. 120-133.

Eco, U., Arte e bellezza nell'estetica medievale, Milano, La nave di Teseo, 2016.

Faes de Mottoni, B., "Il commento di Bertoldo di Moosburg all'Elementatio theologica di Proclo. Edizione delle proposizioni riguardanti il tempo e l'eternità", in Studi medievali 12(1971), p. 417-461.

Faes de Mottoni, B., "Il problema della luce nel commento di Bertoldo di Moosburg all'Elementatio theologica di Proclo", in Studi medievali 16(1975), p. 325-352.

Flasch, K., "Einleitung", in Berthold of Moosburg, Expositio super Elementationem theologicam. Prologus. Propositiones 1-13, eds. M.R. Pagnoni-Sturlese, L. Sturlese, Hamburg, Meiner, 1984, p. xi-xxxvii.

Gersh, S., Middle Platonism and Neoplatonism. The Latin Tradition, 2 vols., Notre Dame, In., University of Notre Dame Press, 1986.

Gersh, S., "Proclus as theologian", in S. Gersh (ed.), Interpreting Proclus. From Antiquity to the Renaissance, Cambridge, Cambridge University Press, 2014, p. 80-107.

Imbach, R., "Au-delà de la métaphysique. Notule sur l'importance du Commentaire de Berthold de Moosburg op sur les Éléments de théologie”, in D. Calma (ed.), Reading Proclus and the Book of Causes. Volume 1. Western Scholarly Networks and Debates, Leiden / Boston, Brill, 2019, p. 376-393.

Jeck, U.R., "Die hermetische Theorie des Mikrokosmos in der Metaphysik Alberts des Grossen und im Prokloskommentar des Berthold von Moosburg", in Patristica et Mediaevalia 20(1999), p. 3-18.

Kaeppeli, T., Scriptores Ordinis Praedicatorum Medii Aevi, 4 vols, Roma, Istituto Storico Domenicano, 1970-1993. 
King, E., "Eriugenism in Berthold of Moosburg's Expositio super Elementationem theologicam Procli", in D. Calma (ed.), Reading Proclus and the Book of Causes. Volume 1. Western Scholarly Networks and Debates, Leiden / Boston, Brill, 2019, p. 395-437.

Libera, A. de, Introduzione alla mistica renana, Milano, Jaca Book, 1998.

Ludueña, E., "El politeísmo de Proclo en la Expositio de Bertoldo de Moosburg", in S. Filippi, M. Coria (eds.), La Identidad propia del Pensamiento Patrístico y Medieval. ¿Unidady Pluralidad?, Rosario, Paideia Publicaciones, 2014, p. 393-403.

Magee, J.C., "The Boethian Wheels of Fortune and Fate", in Mediaeval Studies 49(1987), p. 524-533.

Massa, E., "La deificazione nel commento di Bertoldo di Moosburg a Proclo, Elementatio theologica, 129. Edizione del testo e prime analisi", in R. Lievens, E. Van Mingroot, W. Verbeke (eds), Pascua Mediaevalia. Studies voor Prof. Dr. J.M. De Smet, Leuven, Leuven University Press, 1983, p. 545-6o4.

Pagnoni-Sturlese, M.R., “À propos du néoplatonisme d'Albert le Grand. Aventures et mésaventures de quelques textes d'Albert dans le Commentaire sur Proclus de Berthold de Moosburg", in Archives de philosophie 43(1980), p. 635-654.

Pagnoni-Sturlese, M.R., "Filosofia della natura e filosofia dell'intelletto in Teodorico di Freiberg e Bertoldo di Moosburg”, in K. Flasch (ed.), Von Meister Dietrich zu Meister Eckhart, Hamburg, Meiner, 1984, p. 115-127.

Palazzo, A., "La ricezione di un passo ermetico (Asclepius 8) nel tardo medioevo. Ulrico di Strasburgo, Pietro di Tarantasia, Riccardo di Mediavilla, Bertoldo di Moosburg e Dionigi il Certosino", in T. Iremadze, T. Tskhadadze, G. Kheoshvili (eds), Philosophy, Theology, Culture. Problems and Perspectives. Jubilee Volume Dedicated to the 75th Anniversary of Guram Tevzadze, Tbilisi, Publishing House "Nekeri" / Publishing House "Arche", 2007, p. 104-125.

Palazzo, A., "Ulrich of Strasbourg's Philosophical Theology. Textual and Doctrinal Remarks on De summo bono" in A. Speer, Th. Jeschke (eds), Schüler und Meister, Berlin / Boston, De Gruyter, 2016, p. 205-242.

Palazzo, A., "Eckhart's Islamic and Jewish Sources. Avicenna, Avicebron, and Averroes", in J. Hackett (ed.), A Companion to Meister Eckhart, Leiden / Boston, Brill, 2013, p. $253-298$.

Patch, H.R., "Fate in Boethius and the Neoplatonists", in Speculum 4(1929), p. 62-72.

Potestà, G.L., "Per laboriosam investigationem ascendendo. L'edizione di Bertoldo di Moosburg", in Rivista di Filosofia Neo-Scolastica 76(1984), p. 637-643.

Retucci, F., “Magister Thomas Anglicus Minor. Tommaso di York fonte dell'Expositio di Bertoldo di Moosburg", in Quaderni di Noctua. La tradizione filosofica dall'antico al moderno 5(2019), p. 1-41.

Sannino, A., "Berthold of Moosburg's Hermetic Sources", in Journal of the Warburg and Courtauld Institutes 63(2000), p. 243-258. 
Sannino, A., "Il concetto ermetico di natura in Bertoldo di Moosburg", in P. Lucentini, I. Parri, V. Perrone Compagni (eds), Hermetism from Late Antiquity to Humanism. La tradizione ermetica dal mondo tardo-antico all'Umanesimo = Atti del Convegno internazionale di studi, Napoli 20-24 novembre 2001, Turnhout, Brepols, 2003, p. 203-221. Sannino, A., "Il Liber viginti quattuor philosophorum nella metafisica di Bertoldo di Moosburg", in A. Beccarisi, R. Imbach, P. Porro (eds), Per perscrutationem philosophicam. Neue Perspektiven der mittelalterlichen Forschung. Loris Sturlese zum 6o. Geburtstag gewidmet, Hamburg, Meiner, 2008, p. 252-272.

Segonds, A.-Ph., "Philosophie et astronomie chez Proclus", in G. Boss, G. Seel (eds), Proclus et son influence. Actes du Colloque de Neuchâtel, juin 1985, Zürich: Éditions du Grand Midi, 1987, p. 159-177.

Steel, C., "William of Moerbeke, Translator of Proclus", in S. Gersh (ed.), Interpreting Proclus. From Antiquity to the Renaissance, Cambridge, Cambridge University Press, 2014, p. 247-263.

Sturlese, L., "Introduzione" to Berthold of Moosburg, Expositio super Elementationem theologicam Procli. 184-211. De animabus, ed. L. Sturlese, Roma, Edizioni di Storia e Letteratura, 1974, p. xv-xcii.

Sturlese, L., "Il De animatione caeli di Teodorico di Freiberg", in R. Creytens, P. Künzle (eds), Xenia Medii Aevi historiam illustrantia oblata Thomae Kaeppeli O. P., 2 vols, Roma, Edizioni di Storia e Letteratura, 1978, vol. 1, p. 175-247.

Sturlese, L., "Rec. a Alberti Magni Summa theologiae sive de mirabili scientia Dei, Libri I pars 1, Quaestiones 1-50A, ed. D. Siedler, Münster i.W., Aschendorff, 1978", in Annali della Scuola Normale Superiore di Pisa 10(1980), p. 1691-1698.

Sturlese, L., "Proclo ed Ermente in Germania da Alberto Magno a Bertoldo di Moosburg. Per una prospettiva di ricerca sulla cultura filosofica tedesca nel secolo delle sue origini (1250-1350)", in K. Flasch (ed.), Von Meister Dietrich zu Meister Eckhart, Hamburg, Meiner, 1984, p. 22-33.

Sturlese, L., "Note di Bertoldo di Moosburg O.P., scienziato e filosofo", in Freiburger Zeitschrift für Philosophie und Theologie 32(1985), p. 249-259.

Sturlese, L., Storia delle filosofia tedesca nel Medioevo. Il secolo XIII, Firenze, Olschki, 1996.

Sturlese, L., "Presentazione", in Berthold of Moosburg, Tabula contentorum in Expositione super Elementationem theologicam Procli, ed. A. Beccarisi, Pisa, Scuola Normale Superiore, 2000, p. vii-xi.

Sturlese, L., Homo divinus. Philosophische Projeckte in Deutschland zwischen Meister Eckhart und Henrich Seuse, Stuttgart, Kohlhammer, 2007.

Sturlese, L., "Einleitung", to Berthold of Moosburg, Expositio super Elementationem theologicam Procli. Propositiones 136-159, ed. F. Retucci, Hamburg, Meiner, 2007, p. ix-xv.

Sturlese, L., Eckhart, Tauler, Suso. Filosofi e mistici nella Germania medievale, Firenze, Le Lettere, 2010. 